\title{
A Review of \\ Wound Closure Technique-Patient Morbidity Relationship After Wisdom Tooth Surgery \\ Abdurrahman A. Al-Samman
}

ABSTRACT

B.D.S., M.Sc. (OMFS) - Specialized Dental Center in Tikrit / Salahiddin Health Directorate, Ministry of

Background: Surgical removal of impacted mandibular third molars is associated with various postoperative complications like pain, swelling and trismus. These complications influence the patients' quality of life in the week following surgery. Many surgical interventions had been attempted to limit these complications, among them is the wound closure techniques. This study carry out a literature review to evaluate the impact of these techniques on patient morbidity following LM3 surgery.

Materials and method: The MEDLINE and PubMed database was searched for the related studies. Twenty-one randomized prospective clinical trials, that measure part or all of the immediate outcomes, were included.

Results: Twenty-one randomized prospective clinical trials were evaluated. They described the partial wound closure modalities, including single suture technique, the excision of mucosa immediately distal to the second molar, the placement of drain, and a "sutureless" technique.

Conclusion: The role of wound closure techniques on immediate postoperative sequlae revealed a varied opinion among researchers.

\section{KEYWORDS:}

Wisdom tooth surgery, wound closure, pain, swelling, and trismus.

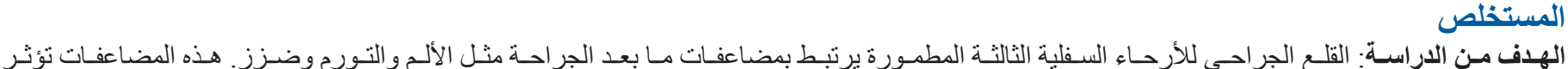

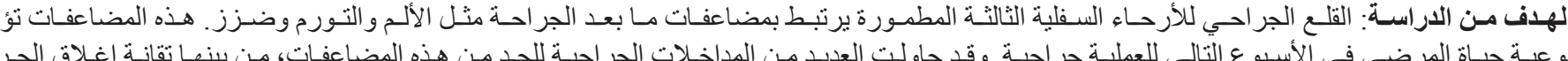

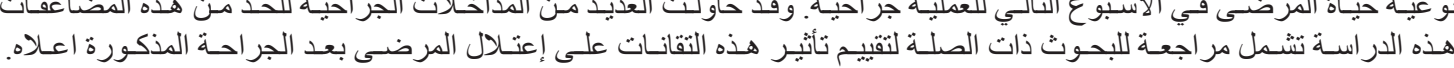

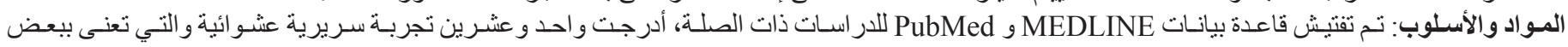

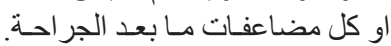

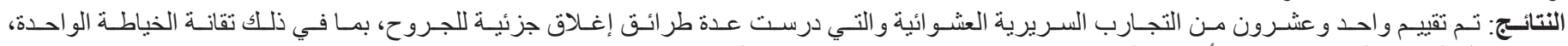

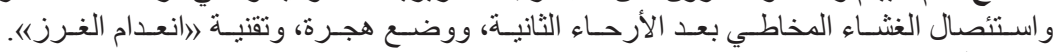

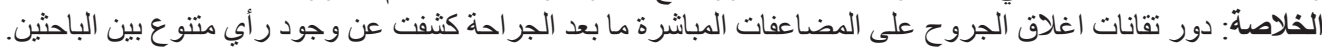

\section{INTRODUCTION}

The removal of impacted mandibular third molars (LM3) is the most performed procedure in oral and maxillofacial surgical practices ${ }^{(1)}$. It involves trauma to the soft and hard tissues, which results in various postoperative complications like pain, swelling and trismus. These complications considered as immediate postoperative outcomes that influence the patients' quality of life in the week following surgery ${ }^{(2)}$. Therefore, reducing these complications becomes imperative.

The severity of pain usually peaks within several hours after surgery and may last for several days or more. Facial swelling may also alarm patients and typically peaks at around one or two days before subsiding over the subsequent days. Trismus results from inflammation of the muscles that move the jaw and may persist for more than a few days causing concern and difficulty in eating for about two weeks or more ${ }^{(3)}$.

Many surgical interventions had been attempted

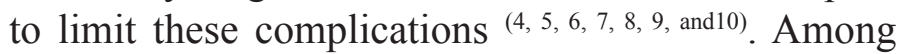
them is the wound closure technique that present with different modalities regarding primary and secondary closure techniques. Primary closure of third molar flaps, the socket is covered and sealed hermetically by a mucosa flap. In the secondary closure technique, the socket remains in communication with the oral cavity to facilitate drainage of inflammatory products. Conflicting opinions have been expressed in published researches concerning these two types of healing ${ }^{(11)}$.

This study carry out a literature review to evaluate the impact of these modalities on patient morbidity following LM3 surgery.

\section{MATERIALS AND METHOD}

The MEDLINE and PubMed database was searched for the related studies using the following keywords: wisdom tooth surgery, wound closure, patient morbidity, pain, swelling, and trismus. Twenty-one randomized prospective clinical trials, that measure part or all of the immediate outcomes, were included.

\section{RESULTS}

The partial closure technique is also described as, secondary closure, and secondary healing by different investigators. Several methods had been described to achieve partial closure, including single suture technique $^{(12,13,14,15 \text { and 16) }}$, the excision of mucosa

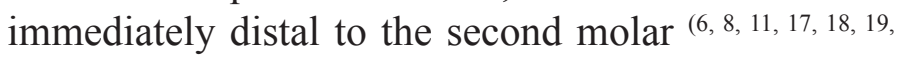


and 20), the placement of drain $(7,21,22,23,24$, and 25), and a "sutureless" technique in which no form of suturing is performed (26, 27, and 28).

\section{Single suture technique}

In the single suture technique, a single suture was placed at the distal relieving incision while in multiple suture technique; the sutures were placed at the interdental papilla between the second and third molars and at the distal relieving incision (Fig.1 and 2).

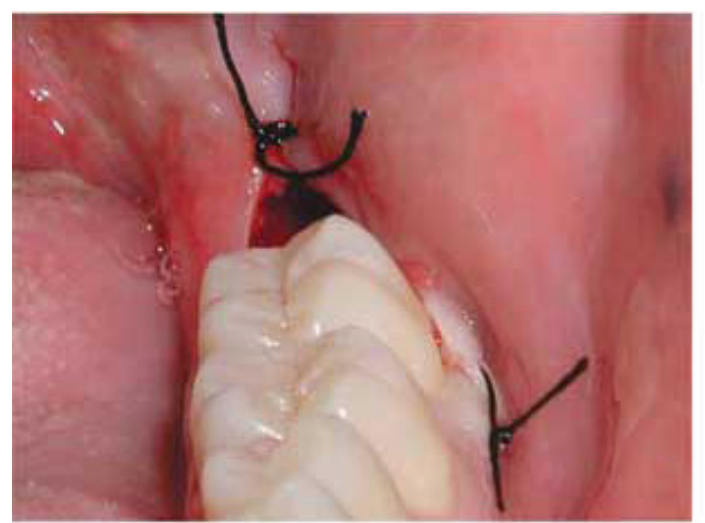

Fig.1: Wound closure by single suture technique: Healing by second intention ${ }^{(14)}$.

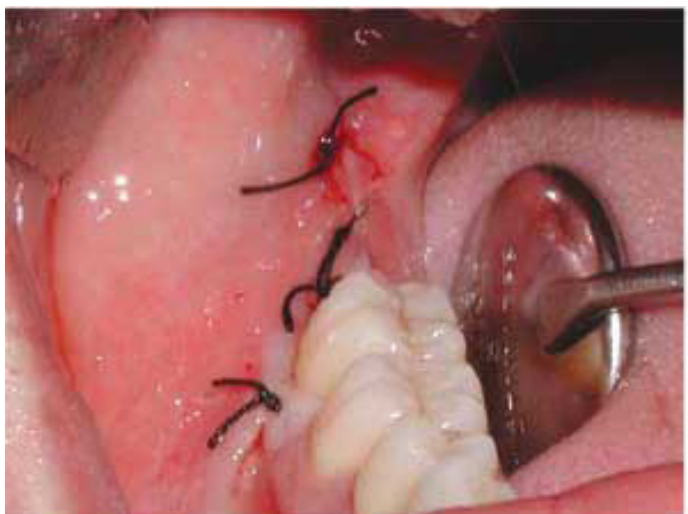

Fig.2: Wound closure by multiple suture technique: Healing by first intention ${ }^{(14)}$.

Five studies were included. Researchers (12, 13, and 14) founded a significant difference in term of pain, swelling and trismus between the two techniques favoring the single suture techniques. In another study, researchers revealed no statistical significant difference between the two techniques ${ }^{(15)}$. Anighoro et al. ${ }^{(16)}$ showed a significant reduction in postoperative pain and trismus in single suture technique, however, no difference in the values of facial swelling when compared with multiple suturing technique. The summery of the above studies seen in table (1).

Table 1. Influence of suturing technique on postoperative secondary outcomes.

\begin{tabular}{|c|c|c|c|c|c|c|}
\hline Study & $\begin{array}{l}\text { Study } \\
\text { design }\end{array}$ & $\begin{array}{l}\text { Sample } \\
\text { size }\end{array}$ & $\begin{array}{c}\text { Age } \\
\text { (Mean) }\end{array}$ & Technique & Outcomes & Results \\
\hline \multirow{3}{*}{ Osunde OD et al. ${ }^{(12)}$} & \multirow{3}{*}{$\begin{array}{c}\text { Parallel } \\
\text { group RCT }\end{array}$} & \multirow{3}{*}{25} & \multirow{3}{*}{$\begin{array}{l}18-38 \\
(26)\end{array}$} & \multirow{3}{*}{$\begin{array}{c}\text { Single/ } \\
\text { Multiple suture }\end{array}$} & Pain & \multirow{3}{*}{ Significant (Favor gp.I) } \\
\hline & & & & & Swelling & \\
\hline & & & & & Trismus & \\
\hline \multirow{3}{*}{ Refo'a Y et al. (13). } & \multirow{3}{*}{$\begin{array}{c}\text { Parallel } \\
\text { group RCT }\end{array}$} & \multirow{3}{*}{16} & \multirow{3}{*}{$>18$} & \multirow{3}{*}{$\begin{array}{c}\text { Single/ } \\
\text { Multiple suture }\end{array}$} & Pain & \multirow{3}{*}{ Significant (Favor gp.I) } \\
\hline & & & & & Swelling & \\
\hline & & & & & Trismus & \\
\hline \multirow{3}{*}{$\begin{array}{c}\text { Sanchis-Bielsa JM, } \\
\text { et al. }{ }^{(14)}\end{array}$} & \multirow{3}{*}{$\begin{array}{c}\text { Split-mouth } \\
\text { RCT }\end{array}$} & \multirow{3}{*}{25} & \multirow{3}{*}{$18-31$} & \multirow{3}{*}{$\begin{array}{c}\text { Single/ } \\
\text { Multiple suture }\end{array}$} & Pain & \multirow{3}{*}{ Significant (Favor gp.I) } \\
\hline & & & & & Swelling & \\
\hline & & & & & Trismus & \\
\hline \multirow{3}{*}{$\begin{array}{c}\text { Gay-Escoda C } \\
\text { et al. }{ }^{(15) .}\end{array}$} & \multirow{3}{*}{$\begin{array}{c}\text { Split-mouth } \\
\text { RCT }\end{array}$} & \multirow{3}{*}{40} & \multirow{3}{*}{$\begin{array}{l}18-45 \\
(25.2)\end{array}$} & \multirow{3}{*}{$\begin{array}{c}\text { Single/ } \\
\text { Multiple suture }\end{array}$} & Pain & \multirow{3}{*}{ Not significant } \\
\hline & & & & & Swelling & \\
\hline & & & & & Trismus & \\
\hline \multirow{3}{*}{$\begin{array}{c}\text { Anighoro EO } \\
\text { et al. }{ }^{(16)}\end{array}$} & \multirow{3}{*}{$\begin{array}{c}\text { Parallel } \\
\text { group RCT }\end{array}$} & \multirow{3}{*}{60} & \multirow{3}{*}{$\begin{array}{l}18-40 \\
(26.8)\end{array}$} & \multirow{3}{*}{$\begin{array}{c}\text { Single/ } \\
\text { Multiple suture }\end{array}$} & Pain & \multirow{3}{*}{ Significant (Favor gp.I) } \\
\hline & & & & & Trismus & \\
\hline & & & & & Swelling & \\
\hline
\end{tabular}

\section{Distal mucosal excision}

In this technique, partial wound closure was achieved by cutting a wedge of mucosa; width 5-6 $\mathrm{mm}$, distal to the second molar, allowing secondary 
wound healing (Fig.3).

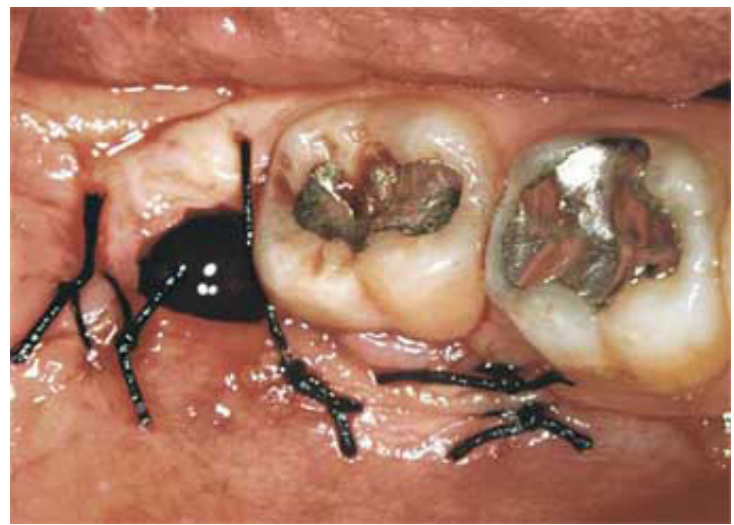

Fig.3: Distal mucosal excision: Healing by second intention (6).
Seven studies were included. Researchers $(6,8,11,17,18,19$, and 20) founded a significant reduction in postoperative pain, swelling when this technique was used as compared with complete closure technique. In addition, Bello et al, ${ }^{(8)}$ revealed a significant reduction in term of postoperative swelling favoring distal mucosal excision technique, however; its effect in reducing postoperative pain and trismus were not significant. In contrast, two studies (17 and 19) showed that trismus was reduced significantly utilizing the distal mucosal excision technique. Table (2) summarizes the included studies that evaluate the effect of mucosal excision technique on postoperative secondary outcomes.

Table 2. Influence of distal mucosal excision on postoperative secondary outcomes.

\begin{tabular}{|c|c|c|c|c|c|c|}
\hline Study & Study design & $\begin{array}{c}\text { Sample } \\
\text { size }\end{array}$ & $\begin{array}{c}\text { Age } \\
\text { (Mean) }\end{array}$ & Technique & Outcomes & Results \\
\hline \multirow{3}{*}{$\begin{array}{l}\text { Maria A } \\
\text { et al. }{ }^{(17)}\end{array}$} & \multirow{3}{*}{ Parallel group RCT } & \multirow{3}{*}{30} & \multirow{3}{*}{$18-40$} & \multirow{3}{*}{$\begin{array}{l}\text { Mucosal excision/ } \\
\text { No mucosal excision }\end{array}$} & Pain & \multirow{3}{*}{ Significant (Favor gp.I) } \\
\hline & & & & & Swelling & \\
\hline & & & & & Trismus & \\
\hline \multirow{2}{*}{$\begin{array}{c}\text { Chaudhary M } \\
\text { et al. }{ }^{(18)}\end{array}$} & \multirow{2}{*}{ Split-mouth RCT } & \multirow[b]{2}{*}{12} & \multirow[b]{2}{*}{$20-30$} & \multirow{2}{*}{$\begin{array}{l}\text { Mucosal excision/ } \\
\text { No mucosal excision }\end{array}$} & Pain & \multirow[b]{2}{*}{ Significant (Favor gp.I) } \\
\hline & & & & & Swelling & \\
\hline \multirow{3}{*}{$\begin{array}{l}\text { Khande K } \\
\text { et al. }{ }^{(19)}\end{array}$} & \multirow{3}{*}{ Parallel group RCT } & \multirow{3}{*}{30} & \multirow{3}{*}{$25-30$} & \multirow{3}{*}{$\begin{array}{l}\text { Mucosal excision/ } \\
\text { No mucosal excision }\end{array}$} & Pain & \multirow{3}{*}{ Significant (Favor gp.I) } \\
\hline & & & & & Swelling & \\
\hline & & & & & Trismus & \\
\hline \multirow{2}{*}{$\frac{\text { Danda AK }}{\underline{\text { et al }}^{(11) .}}$} & \multirow[b]{2}{*}{ Split-mouth RCT } & \multirow[b]{2}{*}{93} & \multirow[b]{2}{*}{$\begin{array}{l}18-31 \\
(24.3)\end{array}$} & \multirow{2}{*}{$\begin{array}{l}\text { Mucosal excision/ } \\
\text { No mucosal excision }\end{array}$} & Pain & \multirow[b]{2}{*}{ Significant (Favor gp.I) } \\
\hline & & & & & Swelling & \\
\hline \multirow{2}{*}{ Kareem JJ (20) } & \multirow{2}{*}{ Parallel group RCT } & \multirow[b]{2}{*}{50} & \multirow[b]{2}{*}{$19-27$} & \multirow{2}{*}{$\begin{array}{l}\text { Mucosal excision/ } \\
\text { No mucosal excision }\end{array}$} & Pain & \multirow[b]{2}{*}{ Significant (Favor gp.I) } \\
\hline & & & & & Swelling & \\
\hline \multirow{2}{*}{$\begin{array}{c}\text { Pasqualini D } \\
\text { et al }^{(6)}\end{array}$} & \multirow{2}{*}{ Parallel group RCT } & \multirow[b]{2}{*}{100} & \multirow[b]{2}{*}{$19-27$} & \multirow{2}{*}{$\begin{array}{l}\text { Mucosal excision/ } \\
\text { No mucosal excision }\end{array}$} & Pain & \multirow[b]{2}{*}{ Significant (Favor gp.I) } \\
\hline & & & & & Swelling & \\
\hline \multirow{3}{*}{$\begin{array}{l}\text { Bello SA } \\
\text { et al }\end{array}$} & & & & & Pain & Not significant \\
\hline & Parallel group RCT & $40 / 42$ & $21-32$ & $\begin{array}{l}\text { Mucosal excision/ } \\
\text { No mucosal excision }\end{array}$ & Swelling & Significant (Favor gp.I) \\
\hline & & & $(26.8)$ & & Trismus & Not significant \\
\hline
\end{tabular}

\section{Placement of drains}

In this technique, a tube drain or gauze drain partially submerged into the extraction socket to secure more drainage and to attain secondary wound healing.

Many studies founded no effect on drain

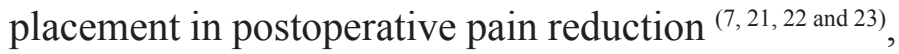
but one study ${ }^{(24)}$ revealed positive drain effect in pain reduction when compared with wound healing without drain placement. When swelling complication was considered, the use of drain was seen to be beneficial through many studies $(7,21,23,24$, and 25$)$. However, Akota et al, (22) recorded a non-significant effect of drain in reducing postoperative swelling. The effect of drain in the reduction of postoperative trismus was conflicting. Researchers documents its validity ${ }^{(7,23}$ and ${ }^{24)}$ and others are not (21, 22 and 25). The summery of the above studies seen in table (3).

Table 3. Influence of drain placement on postoperative secondary outcomes. 


\begin{tabular}{|c|c|c|c|c|c|c|}
\hline Study & Study design & $\begin{array}{c}\text { Sample } \\
\text { size }\end{array}$ & $\begin{array}{c}\text { Age } \\
\text { (Mean) }\end{array}$ & Technique & Outcomes & Results \\
\hline \multirow{3}{*}{$\begin{array}{l}\text { Obimakinde OS } \\
\text { et al. }{ }^{(24) \ldots}\end{array}$} & \multirow{3}{*}{ Parallel group RCT } & \multirow{3}{*}{40} & \multirow{3}{*}{$>18$} & \multirow{3}{*}{$\begin{array}{l}\text { Tube drain/ } \\
\text { No drain }\end{array}$} & Pain & \multirow{3}{*}{ Significant (Favor gp.I) } \\
\hline & & & & & Swelling & \\
\hline & & & & & Trismus & \\
\hline \multirow{3}{*}{$\begin{array}{l}\text { Chukwuneke FN } \\
\text { et al. }{ }^{(7) .}\end{array}$} & \multirow{3}{*}{ Parallel group RCT } & \multirow{3}{*}{50} & \multirow{3}{*}{$\begin{array}{c}18-40 \\
(26)\end{array}$} & \multirow{3}{*}{$\begin{array}{l}\text { Tube drain/ } \\
\text { No drain }\end{array}$} & Pain & Not significant \\
\hline & & & & & Swelling & \multirow{2}{*}{ Significant (Favor gp.I) } \\
\hline & & & & & Trismus & \\
\hline \multirow{3}{*}{$\begin{array}{c}\text { Cerqueira PR } \\
\text { et al. }{ }^{(21)}\end{array}$} & \multirow{3}{*}{ Split-mouth RCT } & \multirow{3}{*}{35} & \multirow{3}{*}{$>18$} & \multirow{3}{*}{$\begin{array}{l}\text { Tube drain/ } \\
\text { No drain }\end{array}$} & Pain & Not significant \\
\hline & & & & & Swelling & Significant (Favor gp.I) \\
\hline & & & & & Trismus & Not significant \\
\hline \multirow{2}{*}{ Sağlam AA ${ }^{(25)}$} & \multirow{2}{*}{ Split-mouth RCT } & \multirow{2}{*}{13} & \multirow{2}{*}{$18-39$} & \multirow{2}{*}{$\begin{array}{l}\text { Tube drain/ } \\
\text { No drain }\end{array}$} & Swelling & Significant (Favor gp.I) \\
\hline & & & & & Trismus & Not significant \\
\hline \multirow{3}{*}{$\begin{array}{l}\text { Akota I } \\
\text { et al. }{ }^{(22)}\end{array}$} & \multirow{3}{*}{ Split-mouth RCT } & \multirow{3}{*}{26} & \multirow{3}{*}{$>18$} & \multirow{3}{*}{$\begin{array}{l}\text { Gauze drain/ } \\
\text { No drain }\end{array}$} & Pain & \multirow{3}{*}{ Not significant } \\
\hline & & & & & Trismus & \\
\hline & & & & & Swelling & \\
\hline \multirow{3}{*}{$\begin{array}{l}\text { Rakprasitkul S } \\
\quad \text { and } \\
\text { Pairuchvej V } \mathrm{V}^{(23) .}\end{array}$} & \multirow{3}{*}{ Split-mouth RCT } & \multirow{3}{*}{23} & \multirow{3}{*}{$>18$} & \multirow{3}{*}{$\begin{array}{l}\text { Tube drain/ } \\
\text { No drain }\end{array}$} & Pain & Not significant \\
\hline & & & & & Swelling & \\
\hline & & & & & Trismus & Significant (Favor gp.I) \\
\hline
\end{tabular}

\section{Sutureless technique}

In the sutureless technique there is free flow of inflammatory exudates from the extraction sockets and allowing the wound to heal secondarily ${ }^{(26)}$.

Three studies were included and the results showed that patients had significantly less postoperative pain, swelling, ${ }^{26,27 a n d ~ 28)}$ and trismus ${ }^{(26)}$ when no sutures were used. Table (4) summarizes the included studies that assess the impact of sutureless technique on postoperative secondary outcomes.

ue on postoperative secondary outcomes.

\begin{tabular}{|c|c|c|c|c|c|c|}
\hline Study & Study design & Sample size & Age (Mean) & Technique & Outcomes & Results \\
\hline \multirow{2}{*}{$\begin{array}{c}\text { Hashemi HM } \\
\text { et al. }{ }^{(26)}\end{array}$} & \multirow[t]{2}{*}{ Split-mouth RCT } & \multirow[b]{2}{*}{30} & \multirow[t]{2}{*}{$19-24(22)$} & \multirow{2}{*}{$\begin{array}{c}\text { Sutureless/ } \\
\text { Multiple suture }\end{array}$} & Pain & \multirow{2}{*}{ Significant (Favor gp.I) } \\
\hline & & & & & Swelling & \\
\hline \multirow{3}{*}{$\begin{array}{l}\text { Osunde OD } \\
\text { et al. }{ }^{(27)}\end{array}$} & \multirow[t]{3}{*}{ Parallel group RCT } & \multirow{3}{*}{40} & \multirow[t]{3}{*}{$18-38(27.1)$} & \multirow{3}{*}{$\begin{array}{c}\text { Sutureless/ } \\
\text { Multiple suture }\end{array}$} & Pain & \multirow{3}{*}{ Significant (Favor gp.I) } \\
\hline & & & & & Swelling & \\
\hline & & & & & Trismus & \\
\hline \multirow[t]{2}{*}{ Kaskos HH ${ }^{(28)}$} & \multirow[t]{2}{*}{ Parallel group RCT } & \multirow[b]{2}{*}{20} & \multirow[b]{2}{*}{$(25.05)$} & \multirow{2}{*}{$\begin{array}{c}\text { Sutureless/ } \\
\text { Multiple suture }\end{array}$} & Pain & \multirow[b]{2}{*}{ Significant (Favor gp.I) } \\
\hline & & & & & Swelling & \\
\hline
\end{tabular}

\section{DISCUSSION}

Swelling, trismus and pain are the most important indicators following surgical extraction of impacted lower third molars ${ }^{(8,9}$ and 11$)$. Wound closure technique is an operative factor that could influence the immediate postoperative pain, swelling, and trismus. It could therefore contribute to the patients' quality of life after surgical operations ${ }^{(8)}$. However, this observation is controversial issue between researchers. The reason for this discrepancy is unclear ${ }^{(16)}$ and might be resulted from variations in the individual inflammatory response ${ }^{(12)}$. In addition, the ability of the surgeon ${ }^{(29)}$ and the difficulty of the operation might influence the outcome of the surgery.

Wound closure technique does not appear to have an influence on the amount of chemical mediators or their stimulation of nerve endings or the interpretation in the central nervous system, which could explain the lack of positive influence of the wound closure technique on pain perception ${ }^{(8)}$. Nevertheless, the accumulation of inflammatory exudate and/ or hematoma increases pressure on nerve endings resulting in more pain perception.

Pain assessment is subjective and influenced by many factors such as the patient's age, sex, and previous experience of pain, pain threshold and tolerance, therefore, assessment of pain may be difficult ${ }^{(30)}$.

Facial swelling could be due to accumulation of inflammatory exudate16 within facial tissues, hematoma collection (31). or both. Partial wound closure, which ensures drainage, appears to minimize immediate postoperative edema, thereby contributing to a reduction in patient discomfort (32). Facial swelling could be measured by different methods like flexible tape, photograph, and the visual analog scale. 
Although they are simple, cost-effective and timesaving methods, but not as accurate as magnetic for the measurements of facial soft tissue volume ${ }^{(33)}$.

Primary closure of the flap avoids suture dehiscence and improves wound healing (34 and 35). In contrast, Pasqualini et al, (6) and Dubois et al, (32) wound dehiscence occurred within the first 1 week postoperatively, more frequently in sockets with total closure. Researchers founded a significantly higher incidence of reactionary bleeding was observed with partial closure when compared the total wound closure ${ }^{(8)}$. It has been postulated that total wound closure will be associated with a higher incidence of dry socket because of the non-self-cleansing nature of the socket. It acts like a 1-way valve that allows food debris to enter the socket but does not allow it to escape from the socket ${ }^{(32)}$.

The possible reason for the lower pain, swelling, and trismus values recorded for the single suture technique might be differences in the retention of the inflammatory exudates which is less in the partial (single suture) closure, because more room is present for the release of the inflammatory exudates compared with the multiple suture technique ${ }^{(12)}$.

Although mucosa excision found to improve

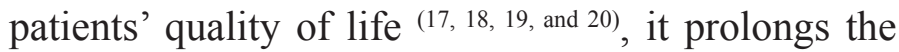
duration of surgery and may cause more trauma to the patient ${ }^{(36)}$ and this may have negative impact on periodontal healing in the distal surface of second molar.

Many studies showed the advantage of drain placement in reducing post-operative swelling $(7,21,23$, ${ }^{24}$, and 25). Chukwuneke et al, ${ }^{(7)}$ recorded a greater pain score for patients who had undergone surgical closure with the insertion of drain, probably because of the irritating effect. In addition, the overall cost of surgery could be increased because of the additional cost of purchasing rubber drains. Insertion of a drain could prolong the duration of surgery and may present with more discomfort to the patient due to the presence of a foreign body in form of a tube or gauze inside the mouth for a varying period of 48 to 72 hours after surgery ${ }^{(36)}$.

Waite and Cherala has described this technique ${ }^{(9)}$. They reported less pain because of free flow of inflammatory exudates from the extraction sockets ${ }^{(27)}$. The benefits of this technique are the lower cost, less operative time, less manipulation of soft tissue and hence, less postoperative morbidity. Moreover, it does not require additional hospital visits for removal of sutures ${ }^{(9 \text { and } 27)}$. A sutureless technique might, however, be limited to cases in which minimal incisions are used for third molar surgery ${ }^{(9 \text { and } 34)}$. The main drawback of suture-less is that healing may be delayed. In addition, there may be high potential for the formation of a periodontal pocket in relation to the adjacent second molar ${ }^{(27)}$. However, Hashemi et al, ${ }^{(26)}$ showed, after 6-month follow up, that secondary wound healing through sutureless technique did not increase the depth of the pocket around the second molar.

\section{CONCLUSION}

The role of wound closure technique on immediate postoperative sequlae revealed a varied opinion among researchers.

Single suture technique and the distal mucosal excision may be valuable in reducing some of postoperative complications.

A sutureless technique might be advantageous in cases in which minimal incisions are used.

However, a recent meta-analysis concludes that there are no significant differences on the outcome between complete and partial wound closure and it refers that the available studies are heterogeneous and do not produce high level of scientific evidence ${ }^{(37)}$.

\section{CONFLICT OF INTEREST}

The authors declare there is no conflict of interest.

\section{Acknowledgement}

I; the author; gratefully acknowledge assistant professor Dr. Mohammad S. Suleiman; a person who taught me how scientific researches are conducted.

\section{REFERENCES}

1. Nageshwar N. Comma incision for impacted mandibular third molars. J Oral Maxillofac Surg 2002; 60(12):1506-9.

2. Lopes V, Mumenya R, Feinmann C, Harris, M. Third molar surgery: an audit of the indications for surgery, postoperative complaints and patient satisfaction. Br J Oral Maxillofac Surg 1995; 33: 33-5.

3. Coulthard P, Bailey E, Esposito M, Furness S, Renton TF, orthington HV. Surgical techniques for the removal of mandibular Wisdom teeth. Cochrane Database of Systematic Reviews 2014, Issue 7.

4. Dolanmaz D, Esen A, Isik K, Candirli C. Effect of 2 flap designs on postoperative pain and swelling after impacted third molar surgery. Oral Surg Oral Med Oral Pathol Oral Radiol. 2013;116 (4):e244-6.

5. Barone A, Marconcini S, Giacomelli L, Rispoli L, Calvo JL, Covani U. A randomized clinical evaluation of ultrasound bone surgery versus traditional rotary instruments in lower third molar extraction. J Oral Maxillofac Surg 2010;68(2):330-6.

6. Pasqualini D, Cocero-Castella A, Mela L, Braccco P. Primary and secondary closure of the surgical wound after removal impacted mandibular third molars: a comparative study. Int J Oral Maxillofac Sur 2005; 34(1):52-57.

7. Chukwuneke FN, Oji C, Saheeb DB. A comparative study of the effect of using a rubber drain on postoperative discomfort following lower third molar surgery. Int J Oral Maxillofac Sur 2008; 37(4):341-4. 
8. Bello SA, Olaitan AA, Ladeinde AL. A randomized comparison of the effect of partial and total wound closure techniques on postoperative morbidity after mandibular third molar surgery. J Oral Maxillofac Surg 2011; 69: e2430 .

9. Waite PD, Cherala S. Surgical outcomes for suture-less surgery in 366 impacted third molar patients. J Oral Maxillofac Surg 2006; 64:669-673.

10. Renton T, Hankins M, Sproate C, McGurk M. A randomised controlled clinical trial to compare the incidence of injury to the inferior alveolar nerve as a result of coronectomy and removal of mandibular third molars. Br J Oral Maxillofac Surg 2005; 43(1): 7-12.

11. Danda AK, Tatiparthi MK, Narayanan V, Siddareddi A. Influence of Primary and Secondary Closure of Surgical Wound After Impacted Mandibular Third Molar Removal on Postoperative Pain and Swelling-A Comparative and Split Mouth Study. J Oral Maxillofac Surg 2010; 68:309312.

12. Osunde OD, Saheeb BD, and Adebola RA: Comparative Study of Effect of Single and Multiple Suture Techniques on Inflammatory Complications After Third Molar Surgery. J Oral Maxillofac Surg 2011; 69:971-76.

13. Refo'a Y, Ouatik N, Golchin F, Mahboobi N. Comparing primary and secondary wound healing discomfort after mandibular third molar surgery: a randomized, doubleblind clinical trial. Gen Dent. 2011; 59(4):310-3.

14. Sanchis-Bielsa JM, Hernández-Bazán S, Peñarrocha-Diago M. Flap repositioning versus conventional suturing in third molar surgery. Med Oral Patol Oral Cir Bucal 2008; 13(2):E138-42

15. Gay-Escoda C, Gómez-Santos L, Sánchez-Torres A, Herráez-Vilas JM. Effect of the suture technique on postoperative pain, swelling and trismus after removal of lower third molars: A randomized clinical trial. Med Oral Patol Oral Cir Bucal 2015, doi:10.4317/medoral.20307.

16. Anighoro1 EO, Gbotolorun OM, Adewole RA, Arotiba GT, Effiom OA. Assessment of the effect of wound closure technique on postoperative sequaele and complications after impacted mandibular third molar extraction. OJST 2013; 3: 527-532.

17. Maria A, Malik M, Virang P. Comparison of primary and secondary closure of the surgical wound after removal of impacted mandibular third molars. J. Maxillofac. Oral Surg 2012; 11(3):276-283.

18. Chaudhary M, Singh M, Singh S, Singh SP, Kaur G. Primary and secondary closure technique following removal of impacted mandibular third molars: A comparative study. Natl J Maxillofac Surg 2012; 3(1): 10-14.

19. Khande K, Saluja H, Mahindra U. Primary and secondary closure of the surgical wound after removal of impacted mandibular third molars. J Maxillofac Oral Surg 2011; 10(2): 112-117.

20. Kareem JJ. A Comparison between primary and secondary wound closure after surgical removal of lower third molars according to pain and swelling. MDJ 2008; 5(4): 410-417.

21. Cerqueira PR, Vasconcelos BC, Bessa-Nogueira RV. Comparative study of the effect of a tube drain in impacted lower third molar surgery. J Oral Maxillofac Surg. 2004; 62(1):57-61.

22. Akota I, Alvsaker B, Bjørnland T. The effect of locally applied gauze drain with chlortetracycline ointment in mandibular third molar surgery. Acta Odontol Scand 1998;
56(1):25-29.

23. Rakprasitkul S, Pairuchvej V. Mandibular third molar surgery with primary closure and tube drain. Int J Oral Maxillofac Surg 1997; 26 (3):187-190.

24. Obimakinde OS, Fasola AO, Arotiba JT, Okoje VN, Obiechina AE. Comparative effect of tube drain on post operative inflammatory complications of impacted mandibular third molar surgery. Niger Postgrad Med J 2010; 17 (3):194-199.

25. Sağlam AA. Effects of tube drain with primary closure technique on postoperative trismus and swelling after removal of fully impacted mandibular third molars. Quintessence Int 2003; 34(2):143-147.

26. Hashemi HM, Beshkar M, Aghajani R. The effect of sutureless wound closure on postoperative pain and swelling after impacted mandibular third molar surgery. $\mathrm{Br}$ J Oral Maxillofac Surg 2012; 50: 256-258.

27. Osunde OD, Adebola RA, Saheeb BD. A comparative study of the effect of suture-less and multiple suture techniques on inflammatory complications following third molar surgery. Int. J. Oral Maxillofac. Surg. 2012; 41: 1275-1279.

28. Kaskos HH. Clinical Comparison between Primary and Secondary Closure Techniques of Wound on Pain and Swelling Following Lower Third Molar Surgery. AlRafidain Dent J 2009; 9(2): $211-215$.

29. Sisk AL, Hammer WB, et al. Complications following removal of impacted third molars: the role of the experience of the surgeon. J Oral Maxillofac Surg 1986; 44: 855-859.

30. Gaya MVO, Capilla MV, Mateos RG. Relation of patient and surgical variables to postoperative pain and inflammation in the extraction of third molars. Med Oral 2002; 7:360-90.

31. Alkan A, Metin M, Arici S, et al: A prospective randomized cross-over study of the effect of local haemostasis after third molar surgery on facial swelling. Br Dent J 197:42, 2004

32. Dubois DD, Pizer ME, Chinnis RJ: Comparison of primary and secondary closure techniques after removal of impacted mandibular third molars. J Oral Maxillofac Surg 11:630, 1982

33. Ustun Y, Erdogan O, Esen E, Karsli E. Comparison of the effects of 2 doses of methylprednisolone on pain, swelling, and trismus after third molar surgery. Oral Surg Oral Med Oral Path Oral Radiol Endod 2003;96(5):535-9.

34. Jakse N, Bankaoglu V, Wimmer G, Eskici A, Pertl C. Primary wound healing after lower third molar surgery: evaluation of 2 different flap designs. Oral Surg Oral Med Oral Pathol Oral Radiol Endod. 2002; 93(1):7-12.

35. Holland CS, Hindle MO. The influence of closure or dressing of third molar sockets on post-operative swelling and pain. Br J Oral Maxillofac Surg. 1984; 22(1):65-71.

36. Ordulu M, Aktas I, Yalcin S, et al: Comparative study of tube drainage versus methylprednisolone after third molar surgery. Oral Surg Oral Med Oral Pathol Oral Radiol Endod 2006; 101:96-100.

37. Carrasco-Labra A, Brignardello-Petersen R, Yanine N, Araya I, Guyatt G. Secondary versus primary closure techniques for the prevention of postoperative complications following removal of impacted mandibular third molars: A systematic review and meta-analysis of randomized controlled trials. J Oral Maxillofac Surg. 2012; 70:441-57. 